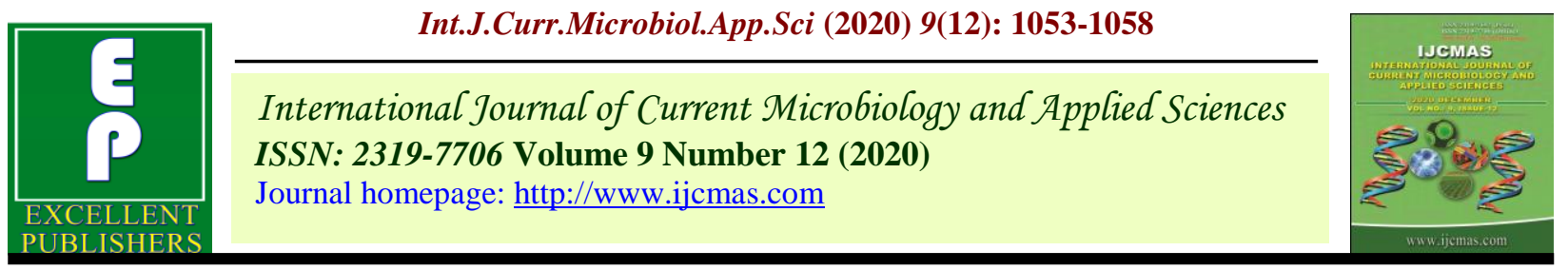

Original Research Article

https://doi.org/10.20546/ijcmas.2020.912.127

\title{
Resource Optimization in Rice through Direct Seeding with Ferti Cum Seed Drill
}

\author{
K. Tejeswara Rao ${ }^{1 *}$, D. Umamaheswara Rao ${ }^{2}$, P. B. Pradeep Kumar ${ }^{2}$ \\ and E. Chandrayudu ${ }^{3}$ \\ ${ }^{1}$ Department of Agronomy, ${ }^{2}$ Department of Extension, ${ }^{3}$ Department of Entomology, District \\ Agricutral Advisory \& Transfer of Technology Centre (ANGRAU), Kondempudi, \\ Visakhapatnam Dt, Andhra Pradesh \\ *Corresponding author
}

\section{A B S T R A C T}

\begin{tabular}{|l|}
\hline K e y w o r d s \\
Direct seeding of \\
Rice (DSR), Ferti \\
Cum Seed Drill, \\
OFDs, Yield and \\
yield attributes, \\
B:C Ratio
\end{tabular}

Paddy is major predominant crop during kharif in Visakhapatnam district of Andhra Pradesh, cultivated in an area of 1,17,608 ha, out of total cropped area of 1,92,638 ha with productivity of $2664 \mathrm{~kg} / \mathrm{ha}$. Production of conventional puddled transplanted rice is facing severe constraints because of water and labour scarcity and climatic changes. Directseeded rice (DSR) is a feasible alternative to conventional puddled transplanted rice with good potential to save water, reduce labour requirement, mitigate green-house gas (GHG) emission and adapt to climatic risks. The yields are comparable with transplanted rice if crop is properly managed. In 2015 \& 2016, efforts have been made in promoting the DSR technology by DAATT Centre, Visakhapatnam. Direct sowing of Rice with Ferti Cum Seed Drill is boon to farmers to save money, time, water and crop comes to harvest 7-10 days earlier than normal transplanted paddy. DAATT Centre, Visakhapatnam has organized On-Farm Demonstrations (OFDs) in farmer fields in two seasons Kharif, 2015andKharif, 2016. Direct sowing of Rice with Ferti Cum Seed Drill recorded 14.74\% more grain yield over normal transplanting method of paddy cultivation during both Kharif seasons. Results from the present study indicated that the farmers realized $75.69 \%$ increase in net income due to increased grain yield by $14.74 \%$ with reduction of cost of cultivation by $17.10 \%$, it could be attributed to reduction in manual labour of 12 man labour and 25 women labour per ha and also increase in yield attributes and yield.

\section{Introduction}

Rice area has been decreasing in state like Andhra Pradesh, although overall productivity is increasing, there is a decrease in compound growth rate in rice productivity at national level (Krishnaiah, 1999). There is no scope for expansion of area for rice cultivation. Rice yields are plateau in the irrigated ecosystem and the rainfed system with low productivity of 2.5 to $3.5 \mathrm{tha}^{-1}$, it has become imperative to increase rice production per unit area per unit time to feed the teaming millions in the new millennium. India has to produce 135-145 million tons by 2020 A.D. to feed the additional 350 million people. To do so, the 
productivity should be raised to $3.2 \mathrm{tha}^{-1}$ by 2020AD from the present level of $2.05 \mathrm{tha}^{-1}$ (The Hindu Survey of Indian Agriculture, 2006).

Visakhapatnam district is one of the rice growing districts in Andhra Pradesh. Farmers grow rice in 1.17 lakh ha during Kharif. Cost of cultivation is rising year by year due to many reasons i.e social reasons, situational factors and input cost. At present cost of cultivation per hectare is between Rs.34250/to Rs 38500/-. This is mainly due escalation of labour wages and scarcity of labour in villages during agricultural season, labour requirement is very intense at the time of transplanting and increase in price of fertilizers.

To overcome this, direct seeding of Rice with Ferti Cum Seed Drill can reduce the labour requirement during transplanting, technology is very simple and can be adopted by the farmers easily, cost of cultivation can be reduced and receive quality crop harvest at 7 10 days earlier than normal transplanted field. Direct seeding of Rice with Ferti Cum Seed Drill technology holds special significance in the present day production system with regard to saving labour component by $30-50 \%$ and increases productivity by $20-30 \%$ (Annual Reports of Directorate of Rice Research, 2012, Rajendranagar, Hyderabad). Direct seeding of Rice with Ferti Cum Seed Drill technology, a new way of cultivation is gaining more attention of farmers in Visakhapatnam District. But the direct seeding of Rice with Ferti Cum Seed Drill technology has its own implications to adopt such as right choice of field, irrigation facilities, varieties, land preparation, weed management and machinery available.

The prime concern of any programme related to agriculture is to enhance productivity and with reduced cost. In order to reduce the cost of cultivation, took initiatives in collaboration with NABARD to promote direct seeding of paddy with Direct seeding of Rice with Ferti Cum Seed Drill in Visakhapatnam district to test the feasibility of Direct seeding of Rice with Ferti Cum Seed Drill through On Farm Trials(OFTs), Method demonstrations to record the yield in Direct seeding of Rice with Ferti Cum Seed Drill technology in comparison with normal method to convince the farmer and to analyze economics of paddy cultivation in District.

\section{Materials and Methods}

Direct seeding of Rice through Ferti Cum Seed Drill technology comparing with normal transplanting method of cultivation, executed On-Farm Demonstrations (OFTs) during Kharif, 2018 and Kharif, 2019 in farmers fields at 20 locations. Direct seeding of Rice with Ferti Cum Seed Drill (Fig.1\&2) is big equipment for sowing dry paddy seed directly in well prepared dry land field is fabricated and it is used for demonstration. There is no need for transplantation. It is a tractor drawn implement. It covers 8 rows of $20 \mathrm{~cm}$ row-torow spacing at a time. It is made up of iron and plastic materials. Salient Features in reduced labour cost, cost on nursery raising, nursery pulling and transplanting can be saved, Uniformity in seed sowing and Plant population, reduction in seed rate and thinning cost. Crop matures 7-10 days earlier than the transplanted paddy Light in weight and easy to handle, an area of 3-4 hectare per day can be shown and saving in seed requirements of $18-20 \mathrm{~kg}$ per acre is sufficient depending on variety. Farmer fields are selected to conduct On Farm Trials (OFTs) with proper drainage facility and regulation of water. The variety cultivated in Direct seeding of Rice with Ferti Cum Seed Drill technology is RGL 2537. Since planting of crop in both Direct seeding of Rice with Ferti Cum Seed Drill technology and Normal transplanting 
method data pertaining to crop stand with number of tillers per hill, number of tillers per square meter, incidence of pests and diseases if any at regular intervals followed by yield contributing parameters like effective tillers, panicles per hill \& square meter and number of grains per panicle are recorded. Yield per $5 \times 5 \mathrm{~m}^{2}$ was collected and calculated per hectare area. Means of yield attributes, yield and cost of cultivation were arrived for yield in both Direct seeding of Rice with Ferti Cum Seed Drill technology and normal transplanting methods. Percent yield increase over normal method was calculated and comparative analysis of cost benefit ratio per hectare was arrived and presented in the tables.

\section{Results and Discussion}

The On-Farm Demonstrations on Direct seeding of Rice with Ferti Cum Seed Drill technology is conducted during Kharif, 2018 and Kharif, 2019 in innovative farmer fields and recorded yield attributes depicted in following tables.

Crop duration: The duration of the crop (Table 1) revealed that there is reduction of duration to reach the harvesting of rice crop. The reduction of crop duration upto10 days was recorded when compared to normal transplantation method of rice cultivation.
The results are corroborates with the Chandrasekhara Rao et al., 2013.

Yield attributes: All yield attributes were recorded better in direct seeding of Rice with Ferti Cum Seed Drill technology than normal method (Table 1). During both seasons of demonstrations in all locations with different varieties indicated that the productive tillers per/Sq.mt, number of grains per panicle ranges from 228 and 200which is more than normal practice 187 and 200 (MSSRF,2002) respectively.

Yield: Recorded more Grain yield (Table 1) to a tune of $14.74 \%$ in Direct seeding of Rice with Ferti Cum Seed Drill method (6575 $\mathrm{kgha}^{-1}$ ) over normal method of cultivation $\left(5730 \mathrm{kgha}^{-1}\right)$. The use of direct seeding of Rice with Ferti Cum Seed Drill is superior to transplanting method of raising the rice crop. Higher yield in Direct seeding of Rice with Ferti Cum Seed Drill technology is contributed by more number of productive tillers, supported by profuse root system resulted in more number of panicles.

Labour involvement in Rice cultivation: There is reduction of laobur utilization (Table 2) in Direct seeding of Rice with Ferti Cum Seed Drill technology i.e., 12 man labour and 25 women labour when compared to normal method of transplanting of rice.

Table.1 Mean data on Yield and Yield attributes of On-Farm Demonstrations on Direct seeding of Rice with Ferti cum Seed Drill technology conducted duringKharif-2018and Kharif, 2019

\begin{tabular}{|c|c|c|c|c|c|c|c|c|c|c|}
\hline \multirow[t]{2}{*}{ Sl.No } & \multirow[t]{2}{*}{ Season } & \multirow[t]{2}{*}{$\begin{array}{c}\text { No. of } \\
\text { Locations }\end{array}$} & \multirow[t]{2}{*}{ Variety } & \multicolumn{2}{|c|}{$\begin{array}{c}\text { No. of } \\
\text { Productive } \\
\text { Tillers/Sq.mt }\end{array}$} & \multicolumn{2}{|c|}{$\begin{array}{c}\text { No. of } \\
\text { Grains/panicle }\end{array}$} & \multicolumn{2}{|c|}{ Yield Kg/ha } & \multirow{2}{*}{$\begin{array}{c}\text { Percentage } \\
\text { Increase in } \\
\text { yield over } \\
\text { check }\end{array}$} \\
\hline & & & & Demo & Control & Demo & Control & Demo & Control & \\
\hline 1 & Kharif 2018 & 3 & $\begin{array}{l}\text { RGL- } \\
2537\end{array}$ & 217 & 192 & 205 & 190 & 6700 & 5620 & 19.22 \\
\hline 2 & Kharif 2019 & 5 & $\begin{array}{l}\text { RGL- } \\
2537\end{array}$ & 238 & 182 & 225 & 210 & 6450 & 5840 & 10.45 \\
\hline & Average & & & 228 & 187 & 215 & 200 & 6575 & 5730 & 14.74 \\
\hline
\end{tabular}


Table.2 Mean of comparative analysis of Cost of Cultivation including labour per hectare of paddy recorded during Kharif-2018and Kharif, 2019

\begin{tabular}{|c|c|c|c|c|c|c|c|c|c|c|c|}
\hline \multirow{3}{*}{$\begin{array}{l}\text { Sl. } \\
\text { No }\end{array}$} & \multirow[t]{3}{*}{ Practice } & \multicolumn{5}{|c|}{ Direct seeding of Rice with Ferti Cum Seed Drill technology } & \multicolumn{5}{|c|}{ Conventional transplantation method } \\
\hline & & \multicolumn{2}{|c|}{ Labour cost } & \multicolumn{2}{|c|}{$\begin{array}{c}\text { Input } \\
\text { cost }\end{array}$} & \multirow{2}{*}{$\begin{array}{l}\text { Total } \\
\text { Cost in } \\
\text { Rs/ha }\end{array}$} & \multicolumn{2}{|c|}{ Labour cost } & \multicolumn{2}{|c|}{ Input cost } & \multirow{2}{*}{$\begin{array}{c}\text { Total Cost } \\
\text { in Rs/ha }\end{array}$} \\
\hline & & No & Cost & Input & Cost Rs & & $\begin{array}{l}\text { No.oflab } \\
\text { our }\end{array}$ & $\begin{array}{l}\text { Cost } \\
\text { Rs/ha }\end{array}$ & Input & Cost Rs & \\
\hline 1. & Nursery management & 0 & 0 & 0 & 0 & 0 & $\begin{array}{l}2 \mathrm{M} \\
\text { preparati } \\
\text { on }\end{array}$ & 600 & FYM & 500 & 1100 \\
\hline 2 & $\begin{array}{l}\text { Seed quantity and } \\
\text { cost }\end{array}$ & 0 & 0 & $\begin{array}{c}50 \mathrm{~kg} / \mathrm{ha} @ \mathrm{Rs} \\
30\end{array}$ & 1500 & 1500 & 0 & 0 & $\begin{array}{c}75 \mathrm{~kg} / \mathrm{ha} @ \mathrm{R} \\
30\end{array}$ & 2250 & 2250 \\
\hline 3 & $\begin{array}{l}\text { Land preparation of } \\
\text { main field }\end{array}$ & $\begin{array}{c}10 \mathrm{M} \\
\text { Sowing }\end{array}$ & 4600 & 0 & 0 & 4600 & $\begin{array}{c}\text { 8M\& } \\
\text { Puddling }\end{array}$ & 5600 & 0 & 0 & 5600 \\
\hline 4 & $\begin{array}{l}\text { Nursery } \\
\text { Pulling and spreading }\end{array}$ & 0 & 0 & 0 & 0 & 0 & $\begin{array}{l}15 \mathrm{M} \\
3 \mathrm{~W}\end{array}$ & 4950 & 0 & 0 & 4950 \\
\hline 5 & Transplanting/ sowing & $5 \mathrm{M} 3 \mathrm{~W}$ & 2000 & 0 & 0 & 2000 & $25 \mathrm{~W}$ & 3750 & 0 & & 3750 \\
\hline 6 & $\begin{array}{l}\text { Manures \& } \\
\text { Fertilizers } \\
\text { management /ha }\end{array}$ & $8 \mathrm{M}$ & 2400 & $\begin{array}{l}\text { DAP- } 125 \mathrm{Kg} \\
\text { Urea } 150 \mathrm{~kg} \\
\text { Mop : } 85 \mathrm{~kg}\end{array}$ & 8000 & 10400 & $8 \mathrm{M}$ & 2400 & $\begin{array}{l}\text { DAP-125Kg } \\
\text { Urea } 150 \mathrm{~kg} \\
\text { Mop : } 85 \mathrm{~kg}\end{array}$ & 8000 & 10400 \\
\hline 7 & $\begin{array}{l}\text { Weeding \& Herbicide } \\
\text { Inter-cultivation }\end{array}$ & $\begin{array}{c}3 \mathrm{M} \\
20 \mathrm{~W}\end{array}$ & 4000 & Herbicides & 2500 & 6500 & $\begin{array}{c}1 \mathrm{M} \\
20 \mathrm{~W}\end{array}$ & 3300 & Herbicide & 1000 & 4300 \\
\hline 8 & Plant protection & $\begin{array}{l}2 \mathrm{M} \\
2 \mathrm{~W}\end{array}$ & 1000 & PP Chemicals & 3500 & 4500 & $\begin{array}{l}4 \mathrm{M} \\
4 \mathrm{~W}\end{array}$ & 1800 & $\begin{array}{c}\text { PP } \\
\text { Chemicals }\end{array}$ & 4500 & 6300 \\
\hline 9 & $\begin{array}{l}\text { Irrigation } \\
\text { management }\end{array}$ & $8 \mathrm{M}$ & 2400 & 0 & 0 & 2400 & $10 \mathrm{M}$ & 3000 & 0 & 0 & 3000 \\
\hline 10 & Harvesting & $27 \mathrm{~W}$ & 5400 & 0 & 0 & 5400 & $25 \mathrm{~W}$ & 5000 & 0 & 0 & 5000 \\
\hline \multirow[t]{2}{*}{11} & $\begin{array}{l}\text { Threshing, } \\
\text { Winnowing and } \\
\text { bagging }\end{array}$ & $\begin{array}{l}16 \mathrm{M} \\
16 \mathrm{~W}\end{array}$ & 8000 & 0 & 0 & 8000 & $\begin{array}{l}16 \mathrm{M} \\
16 \mathrm{~W}\end{array}$ & 8000 & 0 & 0 & 8000 \\
\hline & Total & $\begin{array}{l}52 \mathrm{M} \\
68 \mathrm{~W}\end{array}$ & 29800 & & 15500 & 45300 & $\begin{array}{l}64 M \\
93 W\end{array}$ & 38400 & & 13500 & 54650 \\
\hline
\end{tabular}

M-Male F-Female 
Table.3 Economics of the direct seeding of rice with ferti cum seed drill technology vs normal transplantation method recorded during Kharif-2018 and Kharif, 2019

\begin{tabular}{|c|c|c|c|c|}
\hline Sl.No & Particulars & $\begin{array}{l}\text { Direct seeding of } \\
\text { Rice with Ferti Cum } \\
\text { Seed Drill Method }\end{array}$ & $\begin{array}{c}\text { Transplantation } \\
\text { method }\end{array}$ & Difference \\
\hline 1 & Grain Yield Kg/ha & 6575 & 5730 & 845 \\
\hline 2 & Straw Yield $\mathrm{Kg} / \mathrm{ha}$ & 7680 & 6450 & 1230 \\
\hline 3 & Grain Value (Rs.14/kg) & 92050 & 80220 & 11830 \\
\hline 4 & Straw Value (Rs.0.5 $/ \mathrm{kg}$ ) & 3840 & 3225 & 615 \\
\hline 5 & Gross income Rs./ha & 95890 & 83445 & 12445 \\
\hline 6 & $\begin{array}{l}\text { Total cost of cultivation } \\
\text { Rs./ha }\end{array}$ & 45300 & 54650 & -9350 \\
\hline 7 & Net income Rs./ha & 50590 & 28795 & 21795 \\
\hline 8 & $\mathrm{C}: \mathrm{B}$ ratio & 2.11 & 1.52 & 0.59 \\
\hline
\end{tabular}

Economics: Additional grain yield and straw yield (Table 3) of $845 \mathrm{Kgha}^{-1}$ and $1230 \mathrm{Kgha}^{-1}$ recorded in Direct seeding of Rice with Ferti Cum Seed Drill technology compared with normal practice of transplantation, this could be due to uniform plant population, good tillering capacity. Additional net income of Rs.15434 $\mathrm{ha}^{-1}$ received in Direct seeding of Rice with Ferti Cum Seed Drill technology with reduction of cost of cultivation Rs. 3100 ha $^{-1}$ realized over normal transplanting (Paladugu et al., 2004 and Gupta et al., 2006).

The net income increased by Rs. 15434 per hectare in direct seeding of Rice with Ferti Cum Seed Drill technology. It was mainly due to reduction in cost of transplanting operations. The cost-benefit ration was higher in direct sowing (3.03) which is significantly higher than conventional method (2.41).

In conclusion the results from the present study showed that farmers realized $75.69 \%$ increase in net income due to increased grain yield by $14.74 \%$ with reduction of cost of cultivation by $17.10 \%$, it could be attributed to reduction in manual labour of 15 man labour and 27 women labour and also increase in yield attributes and yield

\section{References}

Annual reports of Indian Institute of Rice Research, 2003, Rajendranagar, Hyderabad.

Chandrasekhararao, C., Jintendra, S., and Murthy, T.G.K. 2013. Resource Optimization in Rice through Direct Seeding by Drum Seeder. International Journal of Agriculture and Food Science Technology. 4: 239-46.

Gupta Raj, K., Ladha, J.K., Singh, S., Singh, R.G., Jat, M.L., Saharawat, Y., Singh, V.P., Singh, S.S., Singh, G., Sah, G., Gathala, M., Gill, M.S., Alam, M., Rehman RAM, Pathak, H., Chauhan, B.S., Bhattacharya, P., and Malik, R.K. 2006. Production technology for directseeded rice. Technical Bulletin 8, New Delhi, India: Rice-Wheat Consortium for the Indo-Gangetic Plains, pp. 16.

Krishnaiah, K., 1999. Rice production in India-CREMNET status and future concerns. Paper presented at $2^{\text {nd }}$ CREMNET Workshop-cum-Group Meeting, 24-27, August 1999, SWMRI, Thanjavur, India.

MSSRF 2002, The System of Rice Intensification-SRI, In: Updates on SRI activities/Progress around the world, 
CIIFAD Report, April, 2004. In: http://ciifad.cornell.edu/sri

Paladugu, S., Thati, S., Lekhi, M., Yadla, S., Poli, R., and Alapati, S., 2004. Studies on varietal performance under SRI and non-SRI. World Rice Research Conference, Nov (5-7), 2004 HELD AT
Tsukuba International Congress Centers (Epochas, Tsukuba), Tsukuba, Ibaraki, Japan Section-26: pp553.

The Hindu Survey of Indian Agriculture, 2006. pp. 5-54.

\section{How to cite this article:}

Tejeswara Rao, K., D. Umamaheswara Rao, P. B. Pradeep Kumar and Chandrayudu, E. 2020. Resource Optimization in Rice through Direct Seeding with Ferti Cum Seed Drill. Int.J.Curr.Microbiol.App.Sci. 9(12): 1053-1058. doi: https://doi.org/10.20546/ijcmas.2020.912.127 